\title{
The role of parents, schools and society in developing civil society in Senior High School
}

\section{Peran orang tua, sekolah dan masyarakat dalam membangun masyarakat kewargaan di Sekolah Menengah Atas}

\author{
Efraim Semuel Nalle, Andy Nabu Sogen, \& Lenny Magdalena Tamunu \\ Department of Social Science Education, Universitas Nusa Cendana \\ Address: Jl. Adisucipto, Penfui-Kupang, East Nusa Tenggara 85001 \\ E-mail: efraimnalle@yahoo.co.id
}

\begin{abstract}
A qualitative research study using the phenomenology and cultural method was conducted in SMA Negeri 4, in Kupang. The data collection techniques were observation, interviews, and documentation. The data was obtained from the informants, and then processed and analysed by using interactive model analysis. The results of this study are 1) the lack of an optimal role from parents in building Civil Society; 2) schools embed the concept of society in their students but need to strengthen the students' character; 3) the Civil Society concept in social life is not implemented properly, and 4) there are some obstacles which result in the absence of good civil society, such as the lack of character education, community high dependency on the government, a lack of facilities in relation to the children's development at school, a lack of political education and political communication, and the practice of nepotism and interests in relation to social justice. The role of society in building a civil society community is still lacking. This is even though, in terms of tolerance and pluralism, parents and schools are already well implemented. However, the aspects of autonomy, democracy and social justice are not working properly, which turn out to be constraints when it comes to civil society formation.
\end{abstract}

Keyword: parents; schools; society; civil society

\begin{abstract}
Abstrak
Penelitian kualitatif dengan metode fenomenologi dan budaya dilakukan di Kota Kupang yang terwakili oleh masyarakat Kelurahan Oesapa dengan konsentrasi pada SMA Negeri 4 Kota Kupang. Teknik pengumpulan data menggunakan observasi, wawancara, dan dokumentasi. Data selanjutnya diolah dan dianalisis dengan menggunakan analisis model interaktif. Hasil penelitian sebagai berikut: 1) Kurang optimalnya perna orang tua dalam membangun masyarakat kewargaan, 2) sekolah secara baik menanamkan konsep masyarakat pada peserta didiknya namun perlu penguatan karakter pada peserta didik, 3) tidak dijalankan secara baik konsep masayarakat kewargaan dalam kehidupan bermasyarakat, dan 4) kendala yang mengakibatkan tidak terbentuknya masyarakat kewargaan secara baik meliputi kurang optimalnya pendidikan karakter, sifat ketergantungan masyarakat yang begitu tinggi kepada pemerintah, kurangnnya fasilitas dalam pengembangan anak di sekolah, kurangnnya pendidikan politik dan komunikasi politik serta, dan adanya praktik nepotisme dan kepentingan dalam pelaksanaan keadilan sosial. Peran masyarakat dalam membangun komunitas masyarakat sipil masih kurang. Hal ini meskipun, dalam hal toleransi dan pluralisme, orang tua dan sekolah sudah dilaksanakan dengan baik, namun aspek otonomi, demokrasi, dan keadilan sosial tidak berfungsi sebagaimana mestinya yang ternyata menjadi kendala ketika menyangkut pembentukan masyarakat sipil.
\end{abstract}

Kata kunci: orang tua; sekolah; masyarakat; masyarakat kewargaan

\section{Introduction}

Civil Society is an independent society, and within certain limits, is capable of improving. It tends to restrict state interference in the reality that has been created as their activities' space (Sujatmiko 2001:40). Furthermore, in the social structure of civil society, there are three (3) social entities: family, civil society, and the state. The family is a space of personal socialisation as a member of a society, which is characterised by harmony, whereas civil society is the location or place of action for various personal interests and groups, especially those related to economic interests (Ubaedillah \& Rozak 2010:179). 
The concept of a civil society can be seen from the free public space states where every citizen has the right to engage in an independent activity in an association or assembly and express their opinion as well as to publish publication which relates to the public interest. The institutionalisation within this public space is through the emergence of volunteers from the social institutions, schools, political parties and mass media, up to the point where the institution is formed by the state as a public service agency (Ubaedillah \& Rozak 2010:181).

Building a civil society is not easy. It needs elements that are a prerequisite for realisation. The main elements that must be possessed include a free public space, democracy, tolerance, pluralism and social justice. In realising these elements, it requires a decent educational environment for the creation of a civil society. Environmental education, according to Ki Hajar Dewantara with Tricentra System (Three Center) theory, stated that (Haryanto 2011:7).

\footnotetext{
"In a child's life, there are three social places that became the centre of education, which are very important. Those are the nature of family, the nature of the school, and the nature of youth movements".
}

If the role of the family (parents), the nature of the school and the nature of the youth movements (society) is well executed, then it will create a civil society within the state. In Indonesia, as a democratic country with a plural society, belief, culture, and language made Indonesia have a strong civil society tradition long before the country itself was established. This can be seen in the various religious social organisations and the national movement in the context of the struggle to gain Indonesian independence. This was alongside with the establishment of Pancasila as the basis of Indonesia as a state, and the motto of 'Bhinneka Tunggal Ika' which unites the pluralistic society into one Indonesia. However, currently, the quality of Indonesian civil society is declining, which can be seen from the Indonesia Democracy Index (IDI) in 2015 announced by the Central Bureau of Statistics. At the national level within the scale from 0-100, the IDI is at 72.82. This figure shows a decline compared to the IDI in 2014, which reached 73.04. This is because the aspect of civil liberties declined from 86.62 to 80.30 ; similar to the aspect of democratic institutions decreasing from 75.81 to 66.87. This is in contrast to the aspect of political rights rising from 63.72 to 70.63 (Berita Resmi Statistik Nasional 2016).

The waning of the civil society concept in Indonesia can be seen from the tendency to strengthen the urge to use the fatwas from religious institutions as a benchmark to validate national behaviour. This phenomenon is not only found in ordinary people, but also among the educated. Although it is not legally binding, in many cases, the fatwa is capable of manipulating state logic, such as MUI issuing the legal provision of "Pluralism, Secularism and Liberalism which contradicts with the Islamic values, Muslims are forbidden to follow those understanding" (Rachman 2010: 6). The Shia and Ahmadiyya community, for example, proposing their own thoughts as the national basis will be different if a fatwa becomes one of the policy considerations to take into account (Haq 2013).

AF research at SMU Negeri in Cianjur, Pandeglang, Surakarta, and Yogyakarta in 2011 found that the culture of civil society has not become mainstream within educational institutions. Religious education has not yet fully entered the convergent space of civic values with religious values based on tolerance and pluralism. Citizenship education has not succeeded in transforming the principle of citizenship into the cognition of the students (AF 2011:174).

In addition, the concept of civil society at the regional level, such as Nusa Tenggara Timur (NTT), has also decreased. This can be seen from the 2014 Indonesia Democracy Index, which was only 68.81 compared to the IDI in 2013, which was 73.29 (News Official Statistics 2015). The decline of IDI in NTT has been illustrated in Figure 1.

Figure 1 shows the right to vote and to be elected rising from 50.26 in 2013 to 73.75 in 2014. The other variables that also increased are free and fair elections. The significant decline in the index can be seen in three of the variables; freedom of expression, the role of political parties, and the freedom 
of assembly and association. The role of Political Parties decreased by 76.96 because 2014 was the year of an election, so the cadre was very poorly implemented by the political parties.

Particularly in Kupang City, the concept of civil society is not new, because the conversation about civil society has been popular, inspired by a national seminar about civil society, defined as "citizen community or citizenship", organised by the Association of Indonesian Political Science (AIPI) in Kupang in 1995. The concept of civil society is popular in Kupang City, which has the motto of 'Kota Kasih' (giving is better than receiving). This is an effort to build people's self-esteem towards independence. If the community grew a disposition of love on a regular basis between one another, this would be the catalyst of civil society creation. There is no arrogance; all people are helping to bring in prosperity together.

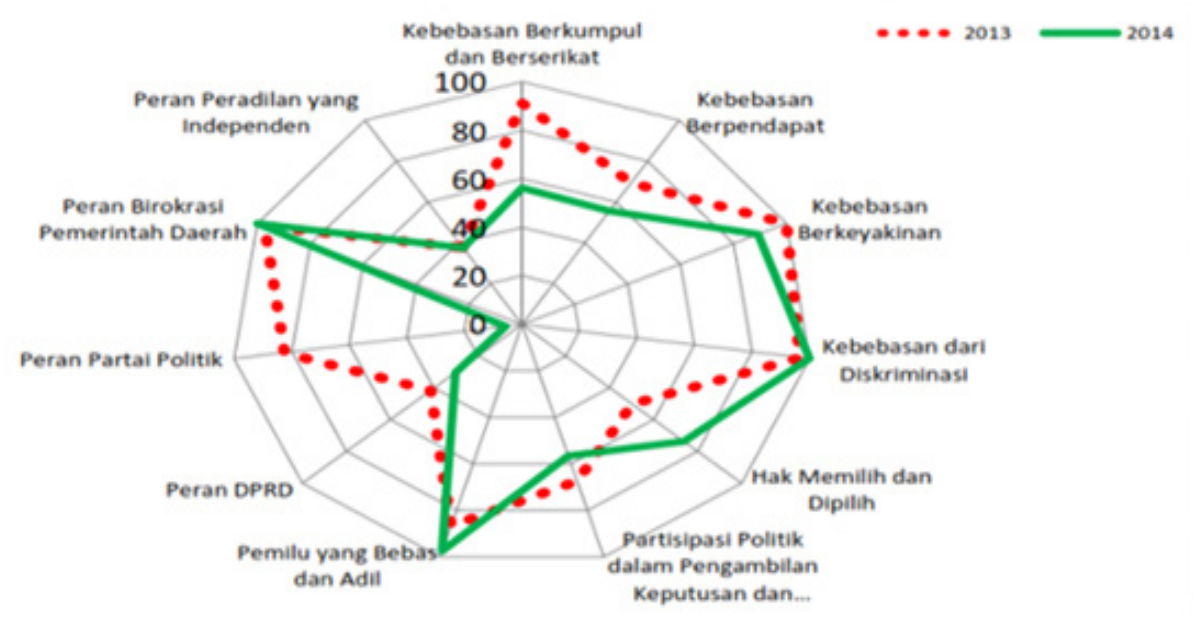

Figure 1.

The development of the variable index IDI NTT, 2013-2014

Source: Berita Resmi Statistik No. 15/08/53/Th. XVIII, 13 August 2015

The concept of civil society is not growing well. This can be seen from the sense of individualism among Kupang City citizens. Giving the reason "time is money", this makes realising Kupang City as 'Kota Kasih' difficult (Raharjo 2006). Two other aspects that also affect the lack of civil society values are parents and schools. The research results from Sontani said that (2012:100) the role of parents in instilling moral values within the family in Kupang City was not arranged and accommodated well, which is shown by the religious, social, economic and exemplary aspects and the aspect of Pancasila. Moreover, parents in Kupang City still like to influence their children to become Civil Servants (PNS), which results in an increasing public dependence on the government. This continues into the level of formal education. The school, for example, is unable to change the mindset of their graduates to find employment in the private sector, therefore a civil servant becomes the main choice.

Furthermore, another problem in Kupang City is the juvenile delinquency that is out of control. For instance, the occurrence of fighting between senior high school students, like SMA Negeri 3 Kupang within Vocational High School and SMK Negeri 2 Kupang on February $2^{\text {nd }}, 2013$, in front of Sistem Administrasi Manunggal Satu Atap (SAMSAT) office Kupang (NTT 2013). This is as well as the fighting between SMA Negeri 4 Kupang and SMK Negeri 1 Kupang that happened on August $15^{\text {th }}$, 2013, in front of the University of Nusa Cendana (NTT 2013). In addition, 53.8\% of adolescents in Kupang City have experienced gender-based violence and sexuality-based violence (KBGS). Throughout 2016, there were 142 cases ( 53 per cent of KBGS cases) and as many as 83 cases $(31.4 \%$ indicating the coercion of sexual intercourse) (NTT Terkini 2016). These civil society problems are complex, therefore, there needs to be a solution in order to create an independent society and within certain limits, for said society to be capable of improving themselves by tending to restrict the state interference in the reality that has been created as its activity space, as Rasyit has said. 
The researchers have focused on the problem of the role of parents, schools and communities in relation to building a civil society in SMA Negeri 4, Kupang City. The question continues on how the learning support in schools improves the quality of civil society. Other questions include how the community carries out its role to support the establishment of civil society and what the constraints are that are faced by the parents, schools and communities when forming a civil society. This study aims to find out the role of parents in building the formation of civil society, how the learning process at school contributes to the improvement of the quality of civil society, how the community performs its role of supporting the formation of civil society, and last but not least, the analysis of the constraints that are faced by parents, schools and communities when forming a civil society.

\section{Research Method}

Civil society is essentially the concept of an independent society that, within certain limits, is capable of improving themselves. It tends to limit the state's intervention to the reality that has been created as its' activity space (Sujatmiko 2001:40). The factors that are the prerequisites for the realisation of this society, according to Eisenstadt (Gafar 2006:180), are autonomy, public access to state institutions, an autonomous public arena, and an open public arena. In addition to the characteristics of a civil society, it can be seen from several basic elements (Ubaedillah \& Rozak 2010:185) that it is a free public area which means that people are able to express their opinions. It is a democractic system where social and political order is derived from and for the citizens, with tolerance and mutual respect for different opinions. Pluralism is the true linkage of diversity in the bonds of civilization and social justice, which is balanced and proportionate, for people share in the rights and duties as a citizen covering all aspects of life such as economics, politics, knowledge, and opportunity.

In realising these essential elements, it requires the involvement of various parties, including parents, schools and society. The family is the first educational institution, which has a very important role especially in relation to building the awareness and development of their children's moral, social, and cultural aspects (Purwaningsih 2010:48). This is as well as including faith education, moral education, physical education, intellectual education, psychic education, social education and sexual education (Hadzuka 2014:2). Moreover, the role of the school consists of developing the student's intelligence, providing knowledge, specialisations, efficiency, socialisation, conservation, cultural transmission and skill development (Hayati 2013). The role of society is to provide education to the community both curricular and non-curricular, as well as professional improvement, community welfare, developing talents and interests and inculcating and improving the moral and spiritual value of society (Ihsan 2010). If the roles aforementioned can be properly implemented, it is not impossible to create a civil society.

In analysing this research, the researcher used the qualitative approach with the phenomenology and cultural method. The purpose is to see how parents and schools transform the culture that they have towards their children, and how society builds the community. The study was conducted in Kupang City, represented by the Oesapa Sub-District community. The sampling was SMA Negeri 4 Kupang. The interviewed subjects were parents who were selected based on their educational level, student achievements, and the delinquency level. Besides the parents, interviews were also conducted with the principal, the vice principal of the curriculum department, a citizenship teacher, religion teacher, scout coach, religious leader and the head of the village. The data collection techniques used were observation, interviews, and documentation. The data obtained was further processed and analysed by using interactive model analysis according to Miles \& Huberman (2007:16), which has three components; data reduction, data presentation and conclusion.

\section{Results and Discussion}

\section{The role of parents in building a civil society}

The criteria of civil society includes autonomy, democracy, tolerance, pluralism and social justice. To support the achievement of these civil society criteria, Adi Suryadi Culla (Hadzuka 2014) concretely 
explained that civil society consists of various networks and social groups. For example, family. Family is defined as a small social group that generally consists of fathers, mothers and children with relatively constant social relationships based on blood, marriage and/or adoption bonds (Ahmadi 2004:167). These units are often interconnected, so each member has a mutual influence on the other members (Fagbeminiyi 2011:47).

The parents have the foremost responsibilities over their children's education (Idi \& Hd 2016:138). They also serve as the most important primary group in society (Ahmadi 2009:104), which is one of the elements of civil society formation. This happens because family is the first place to socialise positive or negative values for and within their children (Salamor 2010). The parents have done their role in building the spiritual character and their child's moral, which includes preaching to the God Almighty, teaching honesty, discipline, politeness and responsiblity. Almost all of the values have been taught by their parents, although some values such as honesty and discipline still need to be strengthened continuously. Therefore, the parents need to build a positive relationship with their children, since this has the tendency to build a better realistic approach to the development of childhood personalities (Ceka \& Murati 2016:61). In building a civil society, it does not only form the spiritual and moral character of the child but also requires for the basic elements to be fulfilled which includes autonomy, democracy, tolerance, pluralism and social justice (Ubaedillah \& Rozak 2010:128) which comprehensively can be described as follows.

First, in terms of autonomy, autonomy itself means an independent society where individuals have the same position to perform social and political transactions. Parents play their part by teaching their children to be independent either intentionally or unintentionally, as their child is often capable of doing the housework including cooking, washing, sweeping, ironing, and their school assignments on their own. On the other hand, children are now very communicative and confident when appearing publicly. This is supported by the informant's information that their children often do liturgy service at church by singing. They also take part as worship leaders or MCs, and often present their work in front of the class. It is not enough to say that the child has achieved independence. Parents forget that their children are not always dependent on them. Parents should also teach their children how to be financially independent. It does not mean that they teach the children how to do business, but they do learn entrepreneur values from an early age. This is in accordance with the ideals of Bung Karno, who wants this nation to be a self-independence nation in terms of the economy. Therefore, the ideal family is a family who is capable of working for their self-prosperity, which then moves forward by encouraging prosperity in the people and the nation (Malik 2016:165).

The second basic element is democracy, which embraces the concept from, by and for the people. Parents do not always provide opportunities for their children to express their opinions, what they want and what they need. They are more authoritarian when making family decisions, whereas when building a democratic society, the parents should be able to provide opportunities and support to their children.

The third element is tolerance. The concept of tolerance is about how, within the society, there is mutual respect and appreciation. The role of the parents in this section has been well executed. It is demonstrated that the parents teach how to respect those who are of a different religion and race. This value is also well received by their children. This was evidenced by the recognition of the parents who stated that their children congratulate their friends during their respective religious celebrations.

The fourth element is pluralism. The concept of plurality is about difference and good manners. The role of parents here has been done well, because the parents are aware that in this life, everyone is different, be it differences in race and religion. Parents always teach children to respect people. They teach their children how to talk to older people, how to be polite, and how to respect the beliefs of others.

The fifth element is social justice. This concept means that rights and responsibilities must be shared in a proportionate balance. The role of parents, in this case, has been done as the same recognition 
is extended towards adopted and biological children. For example, parents always give the same pocket money to all of their children and if there is a cake or food, then it should be shared equally. However, the practice of justice here is not proportional. Parents are more adherent to the concept of commutative justice where something is considered fair if it is divided equally. This is what makes the sense of justice in children equal.

From the description of the basic elements of civil society's formation characteristics, it can be seen that parents have taught their children well about tolerance and pluralism. However, they have not been able to teach their children about autonomy, democracy and social justice. This is strengthened by the research that was conducted by Mayasari (2013:267). The results indicated that there is a negative relationship between democratic parenting and adolescent morality. The research from Sontani (2012) stated that the role of parents in embedding moral values in the family has not been arranged or accommodated well both in relation to the economic aspect, and both the exemplary and basic aspects of Pancasila. This is because the parents have limited relationships with their child's space, since they have the busy lives in order to earn money for their child's future (Sachar 2015:50).

\section{The role of schools in improving the quality of civil society}

Similarly, with the parents at school, they also have an important role in building a civil society community. School serves as the second place, after the home, to educate children. It is an institution which plans for teaching the students under an educator's supervision (Idi \& Hd 2014:142). Furthermore, the school should teach other values which children have not yet learned at home in the order for them to learn something new (Thompson 2002:22). Schools do not only provide only knowledge, but they also provide spiritual education, morals and skills. This is so then after the students have graduated, they will possess good character besides academic knowledge and skills. Similarly, the concept of civil society also demands that the people must have a good attitude, knowledge and skills, which are described in the civil society characteristics such as autonomy, democracy, tolerance, pluralism and social justice.

To support the creation of a civil society that is based on the school's role, it is important to note that the education policy cannot be separated from the political environment (Samsuri 2010). Nonetheless, the school's role in developing the student's intellect, by providing knowledge, specialisation, efficiency, socialisation and conservation, as well as cultural transmission, is capable of cultivating the student's skills (Hayati 2013:161) and successfully educating the student's spiritual and social attitudes. According to the interview results, the observation and documentation of educational character at the schools had not been maximally implemented. In addition, the teacher was also unwilling to record the student's bad behaviour, which made them receive less character building discipline. Spiritual and social attitudes include:

\section{Be piety to the God Almighty}

In this case, the school had been trying to instil this value in accordance with the vision, mission and the objectives of the school through the religious education subject, Civic Education subject, and faith coaching that was conducted every Saturday. This learning needs to be done in a deeper way since, based on the observations, it was found that half of the students were not praying solemnly.

\section{Honest}

Concerning honesty, the school has taught it well. However, there are still some shortcomings, particularly when the students are doing their tasks or exams. Based on the observations, almost all of the students are cheating.

\section{Discipline}

The discipline character is very important when it comes to creating successful people. The school had been trying to create a disciplined atmosphere. However, based on the results of the disciplinary interviews, the student's level of discipline has decreased and there needs to be rule enforcement. 
Many of the students are often late when they are going to school or when they enter the class after break. This problem is also supported by the observation results, which found that the students are frequently not punctual when going home. This was strengthened by the documentation results which found that most of the student's violations were ignoring the task, not collecting assignments and skipping class.

\section{Take responsibility}

Concerning responsibility, the school has tried to embed it well. It can be seen from the informant's acknowledgement that the children are responsible for their assigned tasks. Nevertheless, there are still some irresponsible children. On the other hand, there were also other informants who said different things. Based on the observations and documentation, the children are still less responsible, which portrays the child's behaviour as one who often avoids the responsibility of doing the given task. From taught character, building a civic society are not only done to form the child's spiritual and moral character, but also it requires for the basic elements to be fulfilled, which includes autonomy, democracy, tolerance, pluralism and social justice (Ubaedillah \& Rozak, 2010: 128) which comprehensively can be described as follows.

\section{Autonomy}

The meaning of autonomy in here is about people who can be independent as well as possess the same position when conducting social and political transactions. The school has been embedding these values. The observations show that the students choose to have an independent character and are communicative. It was also supported by the interviewer, who stated that they educate their children in order for them to have soft skills by habituating the children to present in front of the class and to educate the child to be a leader.

\section{Democracy}

In terms of democracy, this school has been practising democracy well. For instance, by way of the voting and elections for the Intra-School Student Organisation (OSIS), such as the determination of the board of the Student Intern Sekolah (OSIS). This is as well as decision-making meetings and the determination of school budgeting through colloquy, which makes the school very transparent. Schools should instil a sense of democracy in the classroom because the observations found that nearly $40 \%$ of students admitted that the classroom decisions were not going through the deliberation consensus process.

\section{Tolerance}

Tolerance at school has been done well. This can be seen from the interview results that demonstrate the school's efforts in instilling appreciation and respect for one another. The school has always celebrated religious feasts with the cooperation of various actors. It also provides space for each religion to perform their worship. This is in parallel with the observation results.

\section{Pluralism}

The pluralism value in this school is very high. The students come from various different backgrounds, including differing in religion, ethnicity and race. These differences have cultivated good manners within the student body. This is proof of the interviewer's observation that the school community has successfully built good relations, harmony, cooperation and encourages helping one another.

\section{Social justice}

The school has been embedding the concept of social justice well. As the interviewer stated, they said that the schools have provided fair assessment to the students, as well as providing assistance for the students with a disability. Besides that, the school has also helped the poor students who are unable 
to pay the full tuition fees by giving them a $50 \%$ discount and providing scholarships. However, there are a few informants who say that there is an injustice that occurs in the schools in the form of task division within the ranks of the teachers. For example, if there is a task that generates an additional income, only certain people are always doing that particular task.

From the description of the civil society formation characteristics above, it can be noted that the school has educated and practised the characteristics well. This is so then the students possess an autonomous character, and practise democracy, tolerance, plurality and social justice. Nevertheless, the schools need to be strengthened in their conducting of spiritual and moral education. This includes Be Piety to the God Almighty, and being disciplined, honest and responsible, which is in line with the lack of character education in SMA Negeri 4 Kupang. AF stated that religious education has not fully entered into the convergence space of civil society values such as tolerance and pluralism. Citizenship education has not succeeded in transforming the principle of citizenship into the student's cognitive and conative sphere (AF 2011:74). This problem could be solved if there are good relations between teachers and parents (Westergard 2013).

\section{The role of society in supporting the establishment of civil society community}

The establishment of a civil society community that is conducted by parents and schools is incomplete if there is no support from the community itself. This is because the community serves as the third educational institution after the family and school environment (Ihsan 2010). The establishment of a civil society community is based on the role of the community, which includes providing education, improving community welfare, developing talents and interests as well as culcating and improving the moral and spiritual values of society (Ihsan 2011:59). Starting from the planting of moral values and the spiritual values of aqidah education, Sunday school is conducted every Sunday and Wednesday, and there is also the catecasation education. The reinforcement of faith and morals is also being echoed when worshipping.

The spiritual and moral values of the community, according to most of the community leaders, are already well practised. Nonetheless, there are some which need special attention, since that there are still riots, and people still like to drink excessive amounts of alcohol. There are also some community leaders who say that spirituality and morals have become the last priority in life.

The establishment/planting of spiritual and moral values within society is the first step in building a civil society. Furthermore, the main elements that must be fulfilled to form the characteristics of the civil society community includes autonomy, democracy, tolerance, pluralism and social justice (Ubaedillah \& Rozak 2010:128). Further elements can be comprehensively described as follows.

\section{Autonomy}

The meaning of autonomy in this context is about people who can be independent along with maintaining the same position when conducting social and political transactions. In its implementation, community leaders have facilitated them in being independent in terms of social and political transactions by providing support in the form of facilities and assistance such as providing the space for selling, providing business capital, and giving them working tools such as boats complete with fishery tools. As well as in the field of politics, community leaders who provide reinforcement to the people are willing to participate freely in politics such as in the form of community registration. They also provide the widest opportunity to the public in order for them to express their opinions without restraint. However, the expectation in creating an autonomous community is still far from ideal. The reason behind this is that there are people who receive the tools and assistance, but who do not take care of the tools. If the tool is damaged, they directly sell it. In the case of politics, people tend to be silent and ignore it. This happens because people think that there will be no changes in their life, even if they participate in politics. 


\section{Democracy}

Democracy is also taught to the community, including how to appreciate differences and how to choose what kind of leaders they want. The community leaders also try to invite members of society to use their voting rights. According to them, democracy in Kupang City is still at $40 \%$. The democracy sticker is already there but it attached to the wrong body. This is due to a lack of political education from the political party in question. The education is only limited in terms of preparing for the next election. In political communications, the aspect is also still lacking because it was done only at the time of the election. There are still multiple ID card voters, dead voters, and underage voters. There still a value of "as long as the leader is happy", which makes the leader unwilling to listen or to see their mistakes.

\section{Tolerance}

Regarding tolerance within society, more than half of the public figures argue that it has been good. This can be seen from the existence of a pulpit exchange between the Catholic and the Protestant church, the cooperation between Christianity and Islam in maintaining security during religious celebration, the understanding "for you, your religion, for me, my religion " and the existence of cooperation among citizens to help people in need which does not look their tribe, religion and race when doing so. There are some public figures who say that this tolerance is just camouflage, and that people do not want to start a riot. Therefore, they choose silence and do nothing, but deep inside their hearts, they dislike it.

\section{Pluralism}

The concept of pluralism is about differences that have goodness of character. In the city of Kupang, the rate of diversity is high, encompassing religious, ethnic and racial diversity. Although the diversity is broad, according to the community leaders, they always seek to build good manners and always teach for the population to respect one another.

\section{Social justice}

Social justice is an important matter, because with good social justice, the welfare of society will be guaranteed. In terms of people's welfare, the community leaders such as the head of the village, helps with the registration of poor communities and has made the proposals to the government so that they could be assisted. This includes receiving rice for the poor, direct cash transfers, community economic empowerment funds (PEM), scholarships, and home improvement. In the coastal areas, people receive assistance in the form of a cooperative fund, tents for selling fish, and boats, along with fishing gear assistance.

On the other hand, there is improving the welfare of the religious leaders through their place of worship. The assistance is in the form of giving zakat to the poor people per year and giving the congregation funding development in the form of interest-free loans to the sellers of vegetables, and deaconesses to the widows and orphans.

The problem is that when this practice is being implemented, according to several community leaders, social justice is still not totally being implemented. It can be seen that there is still a partiality practice; the one who is closer receives more assistance, and there is the existence of favouritism (choosing relatives and selecting based on interests).

From the description of civil society's basic elements and formation characteristics above, it can be seen that the community has invested in tolerance and pluralism well. However, the main elements of autonomy, democracy and social justice have not been implemented properly, so then the civil society community cannot be ideally created. This is also supported by Suroto (2015:664) who stated that first, the characteristics of Indonesian society include: (1) pluralistic/diversity, (2) mutual understanding between society members, (3) high tolerance and (4) moral sanctions. Second. 
The obstacles, as well as the challenges in realising Indonesia's civil society model, are: (a) the development of "poor" people and those who feel poor, (b) NGOs and political parties emerge like growing mushrooms in the rainy season, which makes for the increasing of ambiguities", c) the press is growing rapidly and is increasingly sophisticated but society feels pessimist about their life, (d) there are more people with a higher intellect but they tend to be power-oriented and (e) people are less confident when it comes to competition and they always feel inferior. Third, are the challenges faced by the Indonesian people in the future, which are (1) a democratic attitude, (2) a tolerant attitude, (3) mutual understanding, (4) high morals, and being faithful and devoted and (5) having a global perspective.

This is reinforced by the results of research which was conducted by Fajar (2010:1), which stated that the implementation of political parties roles is not accompanied by the implementation of political party functions such as the Instruments of Political Education, properly and correctly.

\section{The constraints in building a civil society community}

Building a civil society community is not easy, since that there are various obstacles which are faced parents, schools and involved communities. These obstacles have been explained as follows: a) character education by the schools has not been totally maximised, which makes the students less pious to God Almighty, dishonest, undisciplined, and irresponsible and not peace-loving; $b$ ) parents do not educate their children to be financially independent, and as a result, the children tend to be dependent on the state in the future; c) a lack of support facilities at schools that disrupts the development of the children; d) there are still some people who think that the current attitude of tolerance is only a camouflage; e) there is a lack of habituation to conduct a consensus deliberation; (f) there is a lack of communicative politics and political education in society; g) the parents tend to teach commutative justice to their children and $h$ ) the existence of nepotism practices and interests in the implementation of social justice.

Concerning these obstacles, AS Hikim (Ubaedillah \& Rozak 2010) stated that the character of civil society in Indonesia is still highly dependent on the state, which results in the community being in the subordinate position, especially for those in the lower social strata.

The next obstacle is seen in Indonesian society, which is very pluralistic. There is a very high amount of social fragmentation within society, whether it comes from economic problems, socio-cultural aspects, ethnicity, as well as politics. These are all things that inhibit the growth and development of civil society, or at least that slows down its development (Gafar 2006:187).

\section{Conclusion}

It is undeniable that the welfare of society includes autonomy, democracy, tolerance, pluralism and social justice, which is the ideal concept when implementing a strong state formation. Civil society does not exist by itself. It requires a system that works well in order to build it. Starting with the parents, schools and communities, these three elements are the most relevant systems required in order to manifest civil society community formation.

Based on the results of this study, it can be concluded that the parents have yet to perform their role optimally. This can be shown from the basic elements involved in the formation of civil society. Although the criteria of tolerance and pluralism have been taught well, however, the civil society is unable to form ideally because one element - democracy - is not being taught well. In terms of autonomy and social justice, parents only partially teach their children, such as more commutative justice than distributive justice. While for the autonomy aspect, the parents have not taught their children to be financially independent.

Different to the parents, the school has performed its role well in building a civil society community, which can be seen in the basic elements of civil society formation. The schools only need to optimise 
in the context of instilling character education in the form of being cautious when it comes to God Almighty, as well as being honest, disciplined and responsible.

The role of society in building a civil society community is still lacking. This is even though, in terms of tolerance and pluralism, parents and schools are already well implemented. However, the aspects of autonomy, democracy and social justice are not working properly, which turn out to be constraints when it comes to civil society formation. This is due to the lack of self-sufficiency in the self-development community, which depends on the government's assistance, a lack of political communication and political education, and the various practices of nepotism and interests within society.

The lack of a good civil society is caused by several obstacles, such as a lack of character education, high public dependence on the government, a lack of facilities in the development of children in schools, a lack of political education and political communication, and the practice of nepotism and interests in the implementation of social justice.

\section{References}

AF AG (2011) Pemetaan Problem Radikalisme di SMU Negeri di 4 Daerah. Jurnal Maarif, 8 (1).

Ahmadi A (2009) Ilmu Sosial Dasar. Jakarta: Rineka Cipta

Ahmadi A (2004) Psikologi Belajar. Jakarta: Rineka Cipta

Berita Resmi Statistik Nasional No. 73/08/Th. XIX, 03 Agustus 2016

Berita Resmi Statistik No. 15/08/53/Th. XVIII, 13 Agustus 2015.

Ceka A \& Murati R (2016) The role of parents in the education of children. Faculty of Philosophy, University of Tetova, 176 no.53A, Tetovo,1200 Macedonia, Faculty of Philosophy, University of Tetova, 1200 Macedonia. Journal of Education and Practice, 7 (5).

Fagbeminiyi FF (2011) The role of parents in early childhood education: A cas study of Ikeja, Lagos State, Nigeria. Covenant University, Ota, Ogun State Global. Journal of Human Social Science, 11 (2).

Fajar WN (2010) Model pendidikan kewarganegaraan sebagai media pendidikan politik bagi kader dalam meningkatkan kesadaran politik (Penelitian grounded theory dalam konteks pendidikan kewarganegaraan di Indonesia). Jurnal Civicus, 16 (1).

Gafar A (2006) Politik Indonesia: Transisi Menuju Demokrasi. Yogyakarta: Pustaka Pelajar.

Hadzuka I (2014) Peran dan Tanggung jawab Keluarga dalam Membentuk Masyarakat Madani. Artikel Perahu Jagat. [Accessed 18 January 2017]. http://perahujagad.Blogspot.co.id/2014/10/ peran-dan-tanggung-jawab-keluarga-dalam.html.

Haq FRU (2013) Intoleransi di Tahun Politik. Kompas Kamis 7 Maret.

Haryanto (2011) Pendidikan Karakter menurut Ki Hajar Dewantara. Jurnal Cakrawala Pendidikan, edisi Khusus Dies Natalis UNY.

Hayati (2013) Fungsi Sekolah dan Implikasinya Bagi Pengembangan Kurikulum. Jurnal 1 (1).

Idi A \& Hd S (2014) Sosiologi Pendidikan: Individu, Masyarakat dan Pendidikan. Jakarta: Raja Grafindo Persada.

Idi A (2016) Etike Pendidikan:Keluarga, Sekolah dan Masyarakat. Jakarta: Raja Grafindo Persada.

Ihsan HF (2010) Dasar-Dasar Kependidikan: Komponen MKDK. Jakarta: Rineka Cipta.

Malik H (2016) Membangun Generasi Berperadaban. Pamulang; Indes Publishing.

Mayasari F (2013) Hubungan antara pola asuh demokratis orang tua Terhadap moralitas pada remaja. Jurnal. Fakultas Psikologi Universitas Semarang

Miles MB dan Huberman AM (2007) Analisis Data Kualitatif. Buku Sumber Tentang MetodeMetode Baru. Jakarta: Universitas Indonesia Press. 
NTT Terkini (2013) Terlibat Tawuran, 18 Pelajar Diamankan. http://www.nttterkini.com/terlibattawuran-18-pelajar-diamankan/.17/01/2017.

NTT Terkini (2016) 53,8 Persen Remaja Kota Kupang Alami Kekerasan Gender. [Accessed 17 January 2017]. http://www.nttterkini.com/538-persen-remaja-kota-kupang-alamikekerasan-gender/.

Purwaningsih E (2010) Keluarga dalam mewujudkan pendidikan nilai: Upaya mengatasi degradasi nilai moral. Jurnal Pendidikan Sosiologi dan Humaniora, I (1).

Rachman BM (2010) Sekularisme, Liberalisme, dan Pluralisme. Jakarta: Gramedia.

Raharjo B (2006) Mewujudkan Kota Kasih dengan Semangat P2KP. Artikel P2KP.

Sachar G (2015) Teacher's positive influence on learner's character formation. International Journal of Educational Research and Technology, (6):49-52.

Salamor L (2010) Peranan Keluaraga dan Sekolah dalam Pelaksanaan Pendidikan Nilai Guna Membentuk Karakter Anak. Prosiding Seminar Aktualisasi Pendidikan Karakter Bangsa. Bandung: Widya Aksara Press.

Samsuri (2010) Transformasi Gagasan Masyarakat Kewargaan (Civil Society) Melalui Reformasi Pendidikan Kewarganegaraan di Indonesia (Studi Pengembangan Kebijakan Kewarganegaraan pada Jenjang Pendidikan Dasar dan Menengah Erah Reformasi). Disertasi, Sekolah Pasacasarjana Universitas Pendidikan Indonesia.

Sontani EN (2012) Studi Tentang Peran Orang Tua dalam Menanamkan Nilai-Nilai Moral dalam Keluarga di TK Pertiwi Kupang di Kelurahan Naikolan Kota Kupang. Skripsi, Program Studi Pendidikan Anak Usia Dini, FKIP UNDANA.

Sujatmiko IG (2001) Wacana civil society di Indonesia. Jurnal Masyarakat, 9.

Suroto (2015) Konsep masyarakat madani di Indonesia dalam masa postmodern (Sebuah analitis kritis). Jurnal Pendidikan Kewarganegaraaan. PPKN, FKIP, Universitas Lambung Mangkurat, Banjarmasin.

Thompson WG (2002) The Effects of Character Education on Student Behavior. Dissertation, the faculty of the Department of Educational Leadership and Policy Analysis East Tennessee State University.

Ubaedillah A \& Rozak A (ed). (2010) Pendidikan Kewargaan (Civic Education): Demokrasi, Hak Asasi Manusai dan Masyarakat Madani, edisi ketiga. Jakarta: ICCI UIN.

Westergard E (2013) Teacher competencies and parental cooperation. University of Stavanger Stavanger, Norway. International Journal about Parents in Education, 7 (2):91-99. 